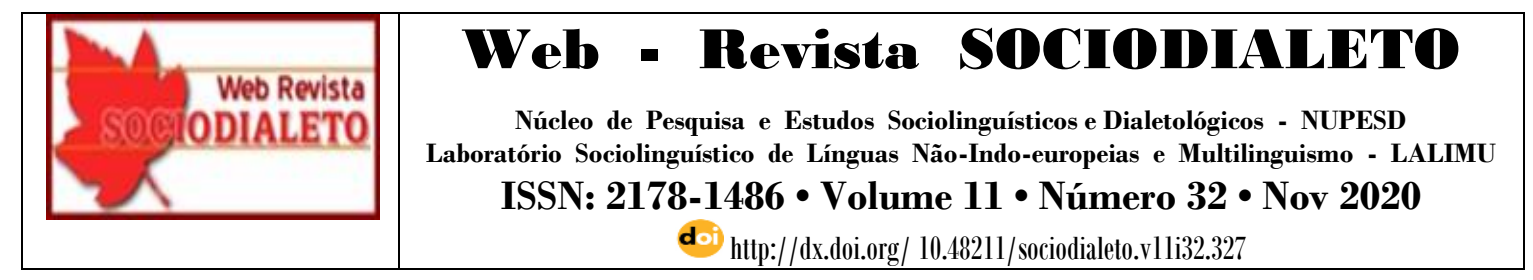

\title{
A INFLUÊNCIA DA ORALIDADE NA PRODUÇÃO TEXTUAL ESCRITA: REVISITANDO O TCC
}

\author{
Fabiana da Silva Lira (PPGL-UNEMAT) ${ }^{1}$ \\ fabiana.vaillant@hotmail.com \\ Jocineide Macedo Karim (PPGL-UNEMAT) ${ }^{2}$ \\ jocineide.karim1@unemat.br
}

\begin{abstract}
RESUMO: O presente artigo apresenta uma síntese do trabalho de conclusão de curso na área da Sociolinguística, intitulado: A influência da oralidade na escrita dos alunos do $1^{\circ}$ ano do Ensino Médio na Escola Estadual "13 De Maio" em Porto Esperidião-MT. O estudo tem como suporte teórico as contribuições da Sociolinguística com o objetivo de identificar a influência da oralidade na escrita dos alunos do $1^{a}$ ano do Ensino Médio. Observamos no resultado das análises das produções textuais escritas dos alunos a presença de onze traços distintos de oralidade. Desse modo, conclui-se que, realmente existem interferências da oralidade na produção escrita de alunos, de maneira que, cabe a nós professores saber como tratar dessas questões nas aulas de Língua Portuguesa.
\end{abstract}

PALAVRAS-CHAVE: Ensino; Escola; Traços de Oralidade; Sociolinguística Variacionista.

\begin{abstract}
The purpose of this article is to summarize the course conclusion work in the area of Sociolinguistics, entitled: The influence of orality in the writing of 1st year high school students at the State School "13 De Maio" in Porto Esperidião - MT. The study had theoretical support to Sociolinguistics. As a result of the analysis, we observed the presence of eleven distinct oral traits in the students' written textual production. Thus, we conclude that there are really interferences of orality in the written production of these students, and it is up to us teachers to know how to deal with these issues. in Portuguese language classes.
\end{abstract}

KEYWORDS: Teaching; School; Traits of Orality; Sociolinguistics Variationist.

\section{Introdução}

A partir do momento que o ser (criança, adolescente ou adulto) chega à escola, já é usuário competente de sua língua materna, pois todo falante tem competência suficiente em sua língua materna para produzir sentenças bem formuladas e comunicar-se com eficiência. Sendo assim, é na escola que ele começa a trabalhar seus recursos

\footnotetext{
${ }^{1}$ Graduada em Letras pela Universidade do Estado de Mato Grosso (UNEMAT). Cáceres-MT/Brasil. Email: fabiana_vaillant@hotmail.com

${ }^{2}$ Professora, Dra. em Linguística do Departamento de Letras/Cáceres, Universidade do Estado de Mato Grosso (UNEMAT). Orientadora do TCC, no ano de 2019. E-mail: jocineide.karim1@unemat.br
} 


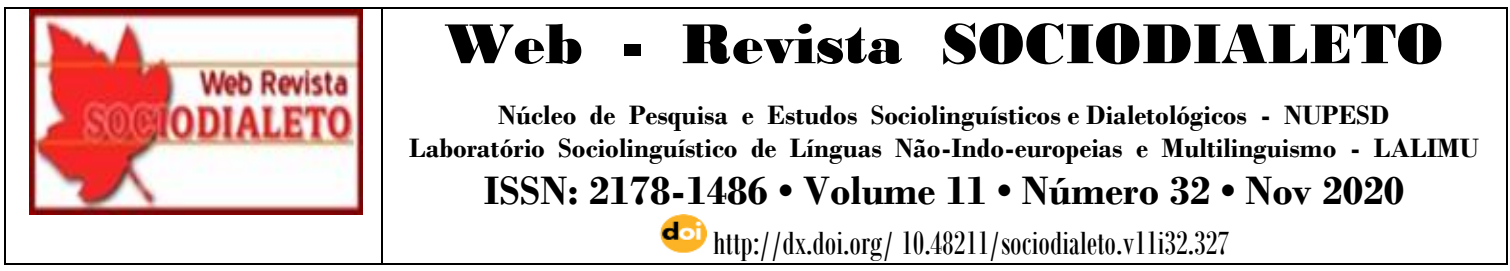

comunicativos para poder atender as convenções sociais que vão definir os usos linguísticos adequados a cada gênero textual, visto que, os usos das línguas são práticas sociais, algumas mais especializadas que exigem vocabulários específicos. Nesse sentido, a escola ajuda aos alunos a adquirir recursos que lhes permitem desempenhar com competência o uso da linguagem em práticas sociais especializadas (BORTONIRICARDO, 2004).

A língua, tanto falada quanto escrita, reflete a organização social, favorecendo as relações humanas com as representações e as formações sociais de uso linguístico. Atualmente, não é mais possível observar as semelhanças ou as diferenças, sem que observemos os usos dessas na vida cotidiana. A princípio, a oralidade e o letramento eram analisados de forma separada, porém, hoje em dia podemos observar que oralidade e letramento são atividades interativas e complementares nas práticas sociais e culturais (MARCUSHI, 2010).

Para realização deste trabalho nos fundamentamos na Sociolinguística, em autores como Alkmim, Amaral, Bagno, Bortoni-Ricardo, Braga, Mollica, Calvet, Câmara Jr., Faraco, Koch, Travaglia, Labov, Macedo-Karim, Marcuschi, Mattoso, Silva e Tarallo, os quais contribuíram com conceitos teóricos para a análise do corpus.

Tendo em vista que, a fala e a escrita são habilidades distintas, no entanto não podemos ignorar suas semelhanças. Conforme afirma Marcuschi (2010, p. 37) "as diferenças entre fala e escrita se dão dentro do continuum tipológico das práticas sociais de produção textual e não na relação dicotômica de dois polos opostos".

Segundo Bortoni-Ricardo (2005), a escola não pode ignorar as diferenças sociolinguísticas, de maneira que o professor deva mostrar aos alunos que existem duas maneiras de dizer a mesma coisa, cada maneira tem seu propósito comunicativo distinto. Todos os alunos têm direito em aprender as variantes linguísticas, não se pode negar a eles esse conhecimento. Sendo assim, o professor deve buscar novas metodologias para trabalhar com os alunos os diferentes traços de oralidade para que esses consigam diferenciar as marcas de oralidade informal de uma mais formal. 


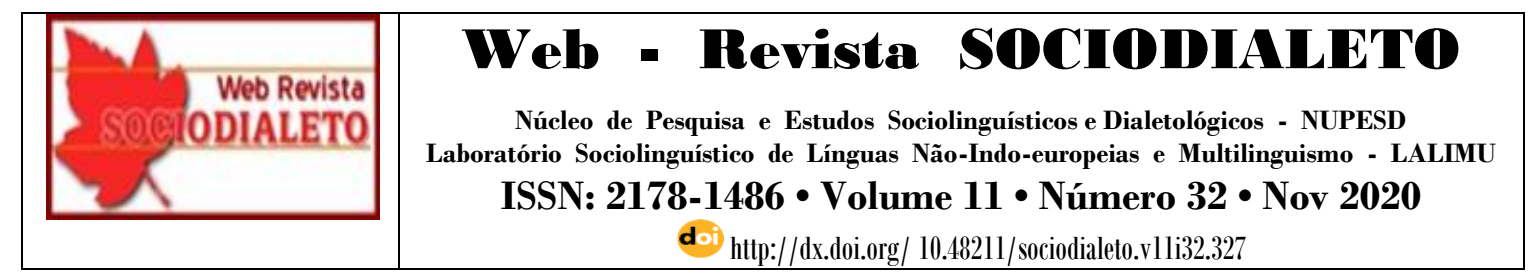

A pesquisa de conclusão de curso - TCC objetivou identificar a influência da oralidade na escrita dos alunos do $1^{\mathrm{a}}$ ano do Ensino Médio, turma D, do período vespertino. A coleta dos dados foi realizada na escola, tomando como corpus as produções escritas dos alunos (texto dissertativo), após a coleta de dados, realizamos a leitura minuciosa de dezessete textos escritos pelos alunos participantes, com idade entre 15 e 17 anos, desse modo, obtivemos o levantamento dos traços de oralidade nos textos e, pôr fim, a análise.

A fim de abordar melhor a discussão sobre oralidade e escrita, dividimos o trabalho em alguns tópicos explicativos, visando o melhor entendimento dos traços de oralidade coletados na produção textual dos alunos, sendo sujeitos seis alunos do sexo feminino e onze alunos do sexo masculino.

\section{O conceito de "erro" para a Sociolinguística: fala e escrita}

De acordo com Bortoni-Ricardo (2006), julgar o conceito de "errado" ou de "certo" não é uma simples tarefa, muitas vezes, a sociedade julga algo como "errado" quando foge da norma "padrão", mas a Sociolinguística analisa a variante empregada e mostra em qual circunstância ela pode ser utilizada. As variações na oralidade são decorrentes de fatos sociais, quando o falante não consegue encaixar a palavra em um momento ou num contexto apropriado. Como podemos observar nas palavras de BortoniRicardo:

O que, muitas vezes, a sociedade estabelece como erro na fala das pessoas, a Sociolinguística considera apenas uma questão de inadequação da forma utilizada às expectativas do ouvinte. Este ouvinte enxerga essa inadequação como uma transgressão das regras gramaticais da estrutura da língua portuguesa, o que, para a Sociolinguística, é visto como uma (in) adequação de certas formas a certos usos (BORTONI-RICARDO. 2006, p. 272). 


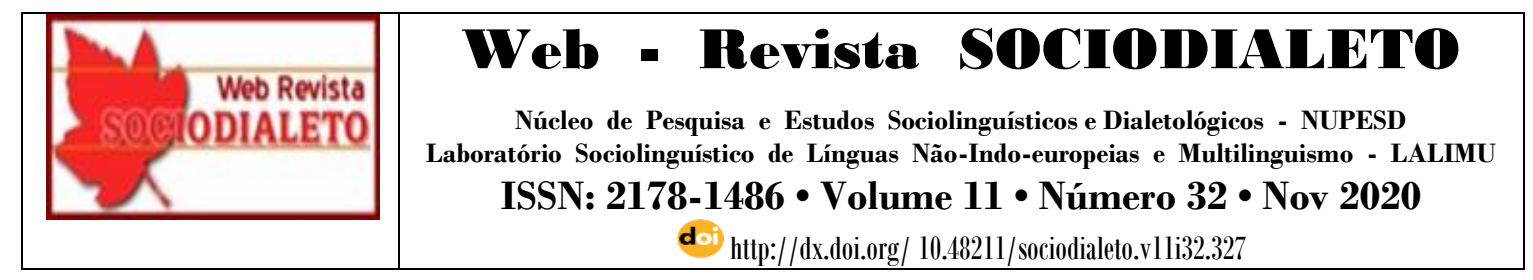

Nessa perspectiva os "erros" na língua oral são considerados fatos sociais pela Sociolinguística, as palavras utilizadas pelos falantes e suas as variações somente serão questionadas fora do seu contexto, esse é considerado seu habitat natural. O exemplo citado se refere ao "erro" na fala, contudo quando ocorre "erro" na escrita, BortoniRicardo observa de outra forma, "quando este erro ocorre na língua escrita representa uma transgressão de um código convencionado e prescrito pela ortografia, que se concretiza como um sistema que não prevê variações" (BORTONI-RICARDO, 2006, p. 273).

Percebemos que o "erro" na oralidade é mais comum e aceito, apenas serão questionados fora do contexto de fala, quando esse é voltado para a escrita, ele é tratado como um problema, considerando-se que o indivíduo transcreve aquilo que fala, devendo seguir a norma de escrita.

Sobre esse aspecto a Profa. Bortoni-Ricardo, na palestra intitulada A linguística na Escola, argumenta:

[...] é necessário que seja feita uma distinção funcional entre erros de ortografia que resultam da integração dos saberes no domínio da oralidade na aprendizagem da escrita e erros que se explicam porque a escrita é regida por um sistema de convenções cujo aprendizado é lento e depende da familiaridade que cada leitor vai adquirindo com a língua escrita. (Informação verbal) (BORTONI-RICARDO, 2004) .

De acordo com Bortoni-Ricardo (2004), podemos observar que, os "erros" tanto na fala quanto na escrita trazem certo incômodo aos professores, pois, não sabem muito bem como lidar com isso, devido aos "erros" serem diferentes entre variedades de línguas. O aluno, muitas vezes, utiliza a variação linguística usada no ambiente familiar, que é regida pela oralidade, em momentos de cultura e letramento, que é a utilizada na escola. É nesse momento que os professores não sabem o que fazer, não sabem se devem corrigir ou não.

${ }^{3}$ BORTONI-RICARDO - A linguística na escola. In: 56ª Reunião Anual da SBPC. Cuiabá, MT, 2004. 


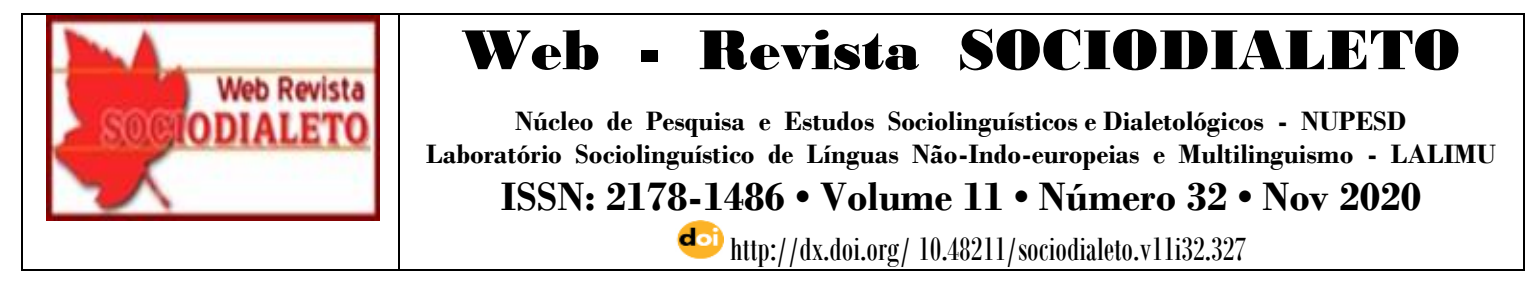

Desse modo, Bortoni-Ricardo (2004) orienta:

\begin{abstract}
Da perspectiva de uma pedagogia culturalmente sensível aos saberes dos alunos, podemos dizer que, diante da realização de uma regra não padrão pelo aluno, a estratégia da professora deve incluir dois componentes: a identificação da diferença e a conscientização da diferença. A identificação fica prejudicada pela falta de atenção ou pelo desconhecimento que os professores tenham a respeito daquela regra. O segundo componente - a conscientização - suscita mais dificuldades. É preciso conscientizar o aluno quanto às diferenças para que ele possa começar a monitorar seu próprio estilo, mas esta conscientização tem de dar-se sem prejuízo do processo de ensino/aprendizagem, isto é, sem causar interrupções inoportunas (BORTONI-RICARDO, 2004, p. 42).
\end{abstract}

Com o passar do tempo à língua vai se modificando, essas modificações dependem dos interesses culturais de cada comunidade. Como diz Cagliari, na obra Alfabetização e Linguística, "[...] todas as variedades, do ponto de vista estrutural linguístico, são perfeitas e completas entre si. O que as diferencia são os valores sociais que seus membros têm na sociedade" (CAGLIARI, 2007, p. 81).

$\mathrm{Na}$ linha de pensamento de Cagliari, percebemos que, toda variedade tem sua importância, tudo isso irá depender de quem é o falante e qual o papel que este exerce na sociedade, além disso, depende do meio que se utilizará para falar e para quem irá falar. Desse modo, o interlocutor sempre fará uma predefinição de fala de acordo com o papel social do receptor, podemos constatar quando Bortoni-Ricardo acrescenta:

[...] uma inadequação da forma utilizada pelo falante relativamente ao que o seu interlocutor esperava ouvir. Inadequação esta que decorre do que os interlocutores imaginam uns dos outros e "dos papéis sociais que estejam desempenhando e das normas e crenças vigentes na comunidade de fala" - (Informação verbal) - (BORTONI-RICARDO, $2004)^{4}$.

${ }^{4}$ BORTONI-RICARDO-A linguística na escola. In: 56 Reunião Anual da SBPC. Cuiabá, 2004. 


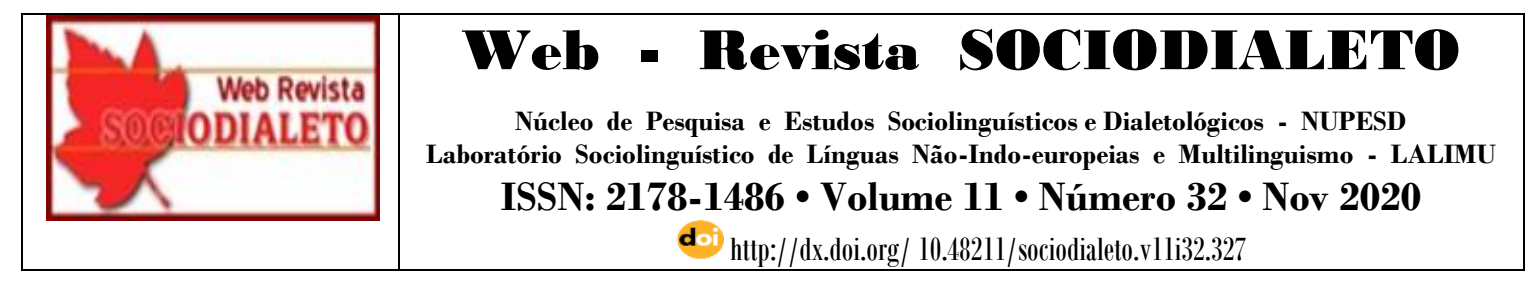

No ato de escrever os alunos sempre buscarão subsídios, por meio de sua língua oral, juntamente com os aprendizados da "norma padrão", porém é importante ressaltar que "saber a ortografia não quer dizer que você sabe a língua, são diferentes tipos de conhecimento que se exige, a ortografia não faz parte da gramática da língua, isto é, das regras de funcionamento da língua" (BAGNO, 2007, p. 131).

Segundo argumenta Bortoni-Ricardo (2004) $)^{5}$, “cada 'erro' de fala ou de escrita deve ser objeto de produtiva discussão entre professor e aluno. Ao discutir os erros com o aluno, este vai verbalizar o caminho do seu raciocínio na decisão de escrever de uma forma ou de outra" (Informação verbal).

Para completar esse pensamento, Bortoni-Ricardo acrescenta:

Um professor não se pode eximir de corrigir uma soma aritmética errada. Não pode também ignorar uma palavra com erro ortográfico. Não se preocupará, porém, em fazer constantes intervenções na língua oral de seu aluno porque sabe que ali ele dispõe de flexibilidade para ajustar seus recursos linguísticos à situação de fala. Um professor poderá aceitar de seu aluno tanto "eu encontrei ele no jardim", quanto "eu o encontrei no jardim", dependendo do contexto em que o enunciado apareça. Mas não poderá jamais aceitar que o aluno escreva: "eu encomtrei..." (BORTONI-RICARDO, 2006, p. 274).

Assim, mesmo que saibamos que existem as variações, não podemos deixar de observar com olhar de sociólogo, como diz Bagno (2007):

O "erro" existe e sua maior ou menor "gravidade" depende precisamente da distribuição dos falantes dentro da pirâmide das classes sociais, que é também uma pirâmide de variedades linguísticas. Quanto mais baixo estiver um falante na sua escala social, maior número de "erros" as camadas mais elevadas atribuirão à sua variedade linguística [...]. O "erro" linguístico, do ponto de vista sociológico e antropológico, se baseia, portanto, numa avaliação negativa que nada tem de linguística: é uma avaliação estritamente baseada no valor social atribuído ao falante, em seu poder aquisitivo, em seu grau de escolarização, em sua renda mensal, em sua origem geográfica, nos

${ }^{5}$ BORTONI-RICARDO- A linguística na escola. In: 56a Reunião Anual da SBPC. Cuiabá, 2004. 


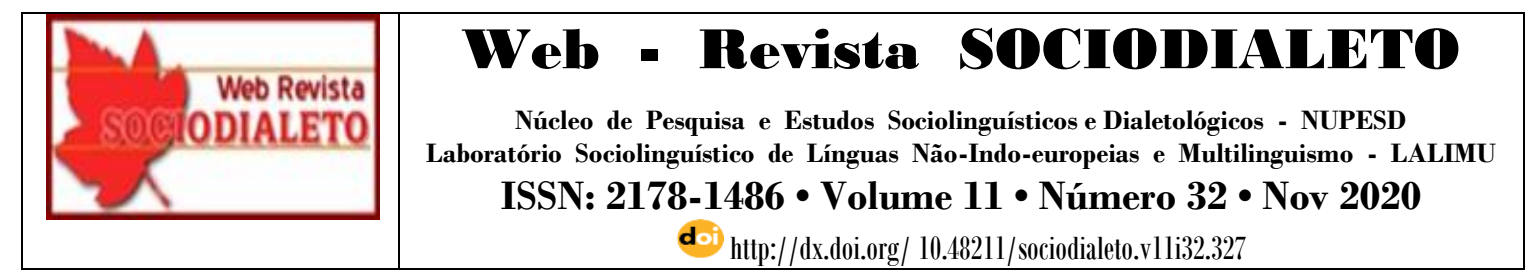

postos de comando que lhe são permitidos ou proibidos, na cor de pele, em seu sexo e outros critérios e preconceitos estritamente socioeconômicos e culturais (BAGNO, 2007, p. 73).

Para não finalizar, Bagno nos tranquiliza, lembrando:

Todo falante nativo de uma língua é um falante plenamente competente dessa língua, capaz de discernir intuitivamente a gramaticalidade ou agramaticalidade de um enunciado, isto é, se um enunciado obedece ou não às regras de funcionamento da língua. Ninguém comete erros ao falar sua própria língua materna, assim como ninguém comete erros ao andar ou respirar (BAGNO, 2007, p. 124).

Portanto, diante dos estudos realizados, percebemos que o "erro" existe, cabe a nós professores saber lidar com ele.

\subsection{Orientação dos PCN’s na produção de texto para o Ensino Médio}

O ensino de língua portuguesa sempre foi, a partir de regras criadas pela sociedade por meio da gramática prescritiva, a que se propõe a descrever regras de como uma língua é realmente falada e a gramática normativa que prescreve como seria o "correto". Elas definem normas que vão determinar o que é apropriado no uso desse idioma, a partir dessas normas classificam como "errada" a variação linguística que se diferenciar da norma culta.

Segundo Faraco (2008):

A expressão norma culta/comum/standard [...] designa o conjunto de fenômenos linguísticos que ocorrem habitualmente no uso dos falantes letrados em situações mais monitoradas de fala e escrita. Esse vínculo com os usos monitorados e com as práticas da cultura escrita leva os falantes a lhe atribuir um valor social positivo, a recobri-la com uma capa de prestigio social (FARACO, 2008, p. 73). 


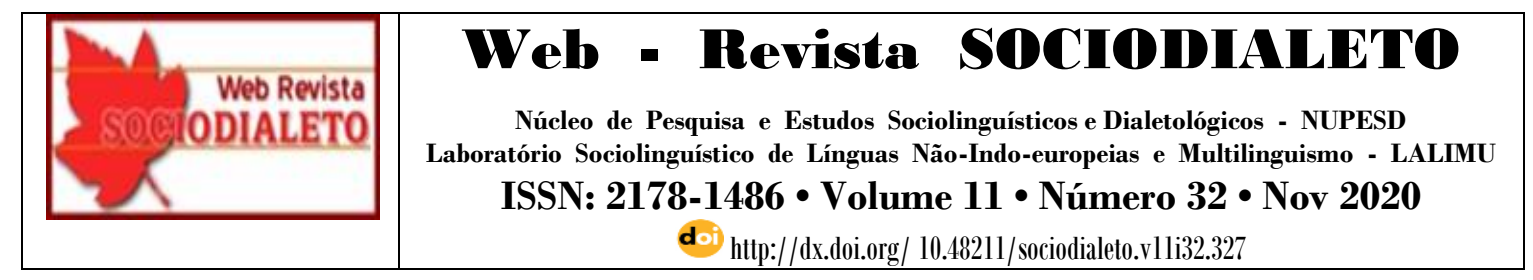

Nesse sentido, a variação linguística é um fenômeno comum a todas as línguas, porém, no espaço escolar, não é completamente acolhida, uma vez que ultrapassa o estudo gramatical sob a abordagem tradicionalista.

Ao pesquisar os Parâmetros Curriculares Nacionais de Língua Portuguesa (PCN's) do Ensino Médio ( $1^{\circ}$ ao $3^{\circ}$ ano), investigamos qual é a abordagem feita sobre a variação linguística.

De acordo com os PCN's:

A questão não é falar certo ou errado, mas saber qual forma de fala utilizar, considerando as características do contexto de comunicação, ou seja, saber adequar o registro as diferentes situações comunicativas [...] é saber, portanto, quais variedades e registro da língua oral são pertinentes em função da intenção comunicativa, do contexto e dos interlocutores a quem o texto se dirige (BRASIL, MEC-SEF, 1997, p. $31)$.

Sendo assim, na orientação prevista nos PCN's não existe a questão de falar “certo" ou "errado", mas em saber dominar a língua, saber adequá-la ao contexto vivente. Desse modo, é fundamental que o educando possa ter participação na sociedade, já que o convívio social lhe permite expressar as suas opiniões e a defender suas ideias.

Os PCN's propõem o ensino da língua portuguesa por meio de variações linguísticas, tomando como base um texto que seja trabalhado como uma unidade básica de reflexão nas séries iniciais, reconhecendo a variação linguística como algo inerente a língua, compreende a variação associada a valores sociais, cabendo à escola cuidar para que não haja o preconceito linguístico.

O foco é trabalhar "a competência comunicativa de um falante que lhe permite saber o que falar com quaisquer interlocutores em quaisquer circunstâncias” BortoniRicardo (2004, p. 73). Essas possibilidades garantem que os alunos interajam com outros apesar de suas diferenças linguísticas. 


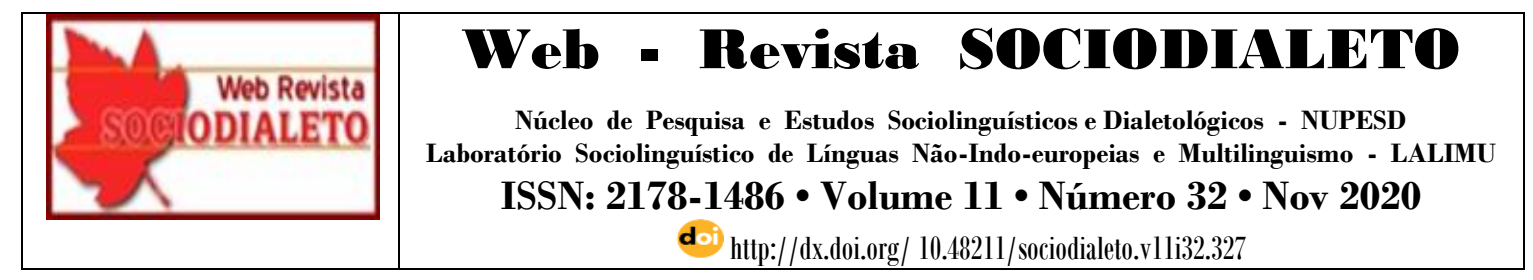

Em relação a definição do texto para os PCN's, “a unidade básica da linguagem verbal é o texto, compreendido como a fala e o discurso que se produz e a função comunicativa" (MEC/SEM, 2000, p.18). Desse modo, "o texto só existe na sociedade e é produto de uma história social e cultural" (MEC/SEM, 2000, p.18).

De acordo com os PCN's.

\begin{abstract}
A linguagem verbal representa a experiência do ser humano na vida social, sendo que essa não é uniforme. A linguagem é construto e construtora do social e gera a sociabilidade. Os sentidos e significados gerados na interação social produzem uma linguagem que, apesar de utilizar uma mesma língua, varia na produção e na interpretação (BRASIL, 2000, p. 20).
\end{abstract}

Verificamos que os PCN's trazem a linguagem verbal como fruto de uma experiência que o ser humano tem, que é adquirido com o convívio na sociedade, considera a linguagem a geradora do social que se transforma em sociabilidade, contudo, essa interação social apesar de utilizar uma mesma língua traz várias formas de interpretação.

Observamos que, a prática da oralidade tem suas características próprias, mas o ser humano não precisa aprender a oralidade, pois este já tem aprendido desde seu nascimento, o que precisa aprender é como usar esta língua em diferentes situações comunicativas, já a prática da escrita é necessária que seja trabalhada em textos de variados gêneros textuais para que o aluno perceba e saiba usar os diferentes usos da escrita.

Vejamos o que os PCN's descrevem sobre a oralidade:

[...] cabe à escola ensinar o aluno a utilizar a linguagem oral no planejamento e realização de apresentações públicas: realização de entrevistas, debates, seminários, apresentações teatrais etc. Trata-se de propor situações didáticas nas quais essas atividades façam sentido de 


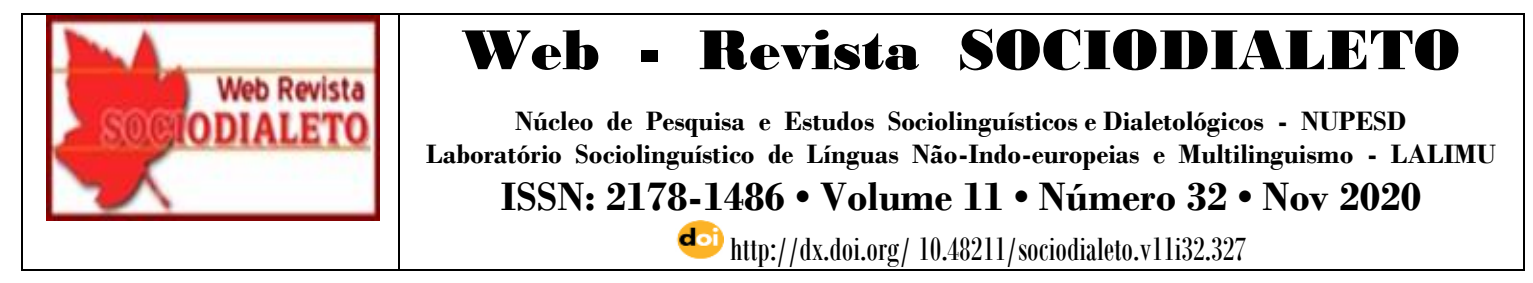

fato, pois é descabido treinar um nível mais formal da fala, tomado como mais apropriado para todas as situações (BRASIL, 1998, p. 25).

Notamos que é papel da escola trabalhar a oralidade com alunos para que estes saibam se comunicar de forma apropriada, falar variando de contextos, onde cada situação exige determinado tipo de monitoramento de fala.

Com base em Koch \& Travaglia (2010) "a coerência textual” observamos a perspectiva que utilizam quanto à competência textual.

[...] o texto é uma unidade linguística concreta (perceptível pela visão ou audição), que é tomada pelos usuários da língua (falante, escritor e ouvinte, leitor), em uma situação de interação comunicativa específica, como uma unidade de sentido e como preenchendo uma função comunicativa reconhecível e reconhecida, independentemente de sua extensão (KOCH \& TRAVAGLIA, 2010, p. 10).

Desse modo, os autores já citados e os PCN’s compreendem a competência textual como uma forma de interação em sociedade. Nota-se que cabe a escola facilitar a ampliação da competência comunicativa dos alunos.

\section{Procedimentos Metodológicos Adotados Neste Estudo}

Apoiamo-nos na área da Sociolinguística, nos autores: citados anteriormente, que nos deram suporte teórico e metodológico para coleta do corpus de pesquisa, tendo como objetivo analisar os traços de oralidade presentes nas produções textuais dos alunos do Ensino Médio. Para tanto, fizemos a coleta de dados na escola, selecionamos o corpus de análise no momento do Estágio Curricular Supervisionado, juntamente com a professora regente da turma do $1^{\circ}$ ano Ensino Médio, na disciplina de língua Portuguesa, na Escola Estadual "13 de Maio", na cidade de Porto Esperidião, durante o $1^{\circ}$ semestre do ano de 2019. 


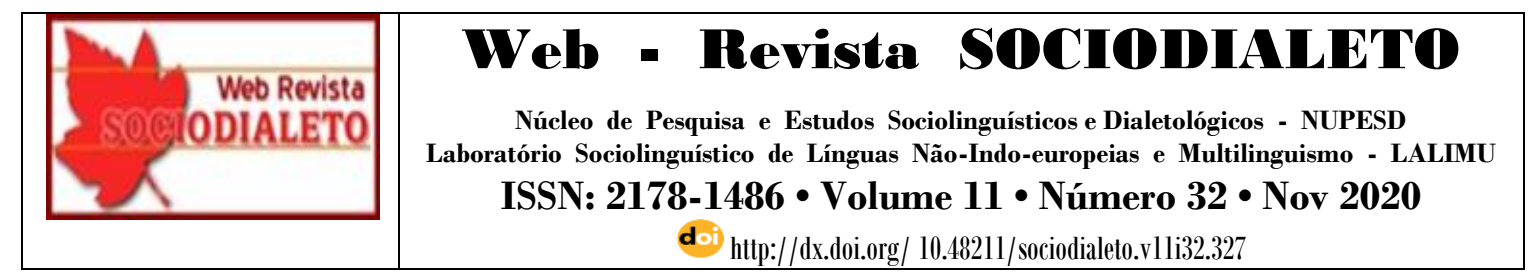

Solicitamos a escrita do gênero conto narrativo a partir de uma imagem selecionada do livro didático, Linguagem e interação, página 51, de Faraco, Moura e Maruxo Jr. A atividade solicitava para o aluno observar uma imagem e produzir uma história. O livro solicitava esta atividade na forma oral, mas trabalhamos como a atividade escrita.

Após a conclusão da escrita, realizamos a leitura das produções elaboradas, observamos a existência ou não de traços de oralidade que serviram posteriormente como corpus para o desenvolvimento da análise desta pesquisa, fizemos a seleção dos fenômenos linguísticos presentes nas produções textuais, embasando nas teorias estudadas no decorrer do trabalho.

A análise foi realizada em duas etapas: a primeira etapa por leitura e separação dos fenômenos encontrados nos textos e a segunda etapa consistiu em levantamento de conceitos pautados na Sociolinguística, tratados pelos autores estudados até aqui e outros que se fizeram necessários para a condução da análise.

\subsection{A coleta de dados}

Para dar início à coleta de dados, realizamos as leituras na área de Sociolinguística, as quais abriram um leque de possibilidades e nos direcionaram a buscar um corpus ideal para sanar a nossa inquietação.

O processo de coleta de dados iniciou-se a partir do momento que escolhemos trabalhar com uma turma do $1^{\circ}$ ano do Ensino Médio, solicitamos a escrita de um texto narrativo, pedimos que os alunos observassem a imagem do livro didático e produzissem um texto narrativo, utilizando os recursos presentes na imagem, após a produção escrita, foram recolhidos os textos e levados para casa, para uma posterior leitura. Durante a leitura, buscou-se os traços de oralidade presentes nas produções textuais, organizando assim o recorte, a partir deste a transcrição dos dados. 


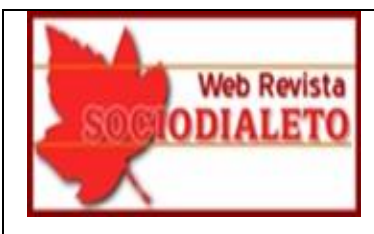

\section{Web - Revista SOCIODIALETO}

Núcleo de Pesquisa e Estudos Sociolinguísticos e Dialetológicos - NUPESD Laboratório Sociolinguístico de Línguas Não-Indo-europeias e Multilinguismo - LALIMU ISSN: 2178-1486 • Volume $11 ・$ Número $32 \bullet$ Nov 2020

doi http://dx.doi.org/ 10.40211/sociodialeto.vlli32.327

Para manter o anonimato dos alunos utilizamos as letras "M" que marca o gênero, sexo masculino e a letra "F", o sexo feminino, o número de meninos é superior ao de meninas.

Com os participantes definidos e as amostras já coletadas iniciamos a separação dos traços de oralidade que ocorreram nos textos, visando formar o envelope de análise.

Retornamos diversas vezes o corpus para esclarecimento de hipóteses na verificação da pesquisa. A seguir, apresentamos uma tabela que mostra as variações encontradas nos textos dos alunos seguidas das formas "correta" da escrita "norma padrão".

Tabela 1- Levantamento de dados

\begin{tabular}{|l|l|l|}
\hline Traços de oralidade selecionados & Dado & Forma padrão \\
\hline Conectivo de continuidade & "Ai" F2 & \\
\hline $\begin{array}{l}\text { o - Mediai, muda-se muitas vezes } \\
\text { em } u .\end{array}$ & "Molheres" F4 & Mulheres \\
\cline { 2 - 3 } & "Corso" M5 & Curso \\
\cline { 2 - 3 } & "Bunito" M7 & Bonito \\
\hline Rotacismo & "Frores" M2 & Flores \\
\hline Abreviação do para o & "Pro" M4 & Para o \\
\hline Abreviação do para & "Pra" M4 & Para \\
\hline Vocalização do fonema /l/ & "Jugado" M5 & Julgado \\
\cline { 2 - 3 } & "Ficol" M5 & Ficou \\
\cline { 2 - 3 } & "Matol" M5 & Matou \\
\cline { 2 - 3 } & "Cansol" M5 & Cansou \\
\hline Hipértese & "Defarsado" M5 & Disfarçado \\
\hline Apócope do [r] final & "Rompe" M6 & Romper \\
\hline Troca do $e$ final pelo $i$ & "Rompiu" M6 & Rompeu \\
\hline Gerundismo & "Engolino" M6 & Engolindo \\
\hline $\begin{array}{l}\text { Vogais tônicas quando seguidas de } \\
\text { ciciante (s ou z), no final dos } \\
\text { vocábulos, se ditongam pela geração } \\
\text { de um i. }\end{array}$ & & Rapaz \\
\hline Monotongação do ditongo [ow] & & \\
\hline
\end{tabular}

Fonte: Tabela elaborada pela autora. 


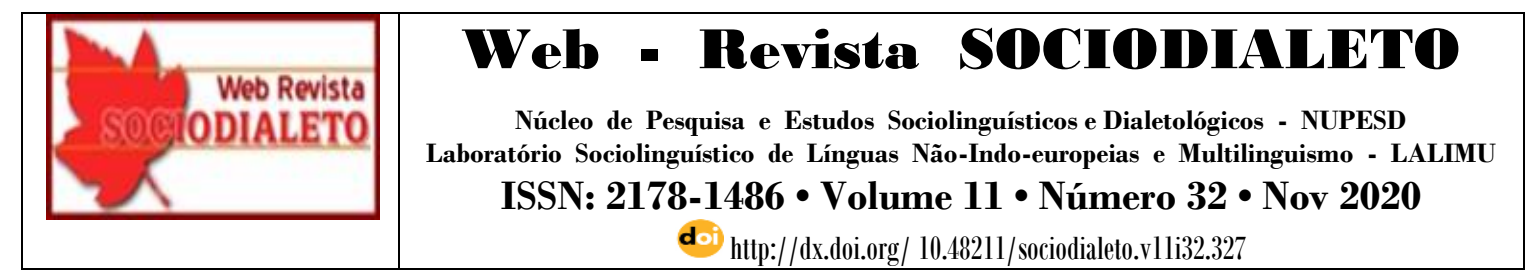

Foram identificados onze traços de oralidade dentre os dezessete textos lidos, alguns textos de alunos tiveram uma grande frequência de utilização de marcas da oralidade. Diante do resultado, percebemos que realmente há a presença de traços de oralidade na produção textual da turma observada. Alguns traços são recorrentes na região em que se encontra o aluno, outros pela baixa formação escolar de parte dos alunos.

A partir dos dados coletados, nos atentamos a escrita de nossos alunos para conduzi-los, a saber, diferenciar onde, de que maneira e para quem falar, o que pode ser transmitido da fala para escrita.

\section{Análise Dos Dados}

Para melhor entendimento dos fenômenos linguísticos observados nos textos analisados, organizamos a apresentação dos traços de oralidade do seguinte modo: primeiro apresentamos o trecho selecionado da produção textual do aluno participante, em seguida destacamos a transcrição do texto com uma breve definição do fenômeno linguístico observado.

A seguir apresentamos os traços mais frequentes encontrados nos textos analisados.

1) Conectivos de continuidade Ai:

O primeiro traço de oralidade analisado ocorreu em três textos, denominado de, Conectivo de Continuidade-ai: a expressão ai foi definida por Marcuschi:

Marcadores são fenômenos que ocorrem na língua, mais precisamente na oralidade, mas que podemos encontrar em textos escritos, esses não contribuem para o desenvolvimento do texto, funcionam quase sempre como articuladores ou determinando (marcando) as expressões de interação entre os interlocutores (MARCUSCHI, 1989, p. 282).

Vejamos outros exemplos: 

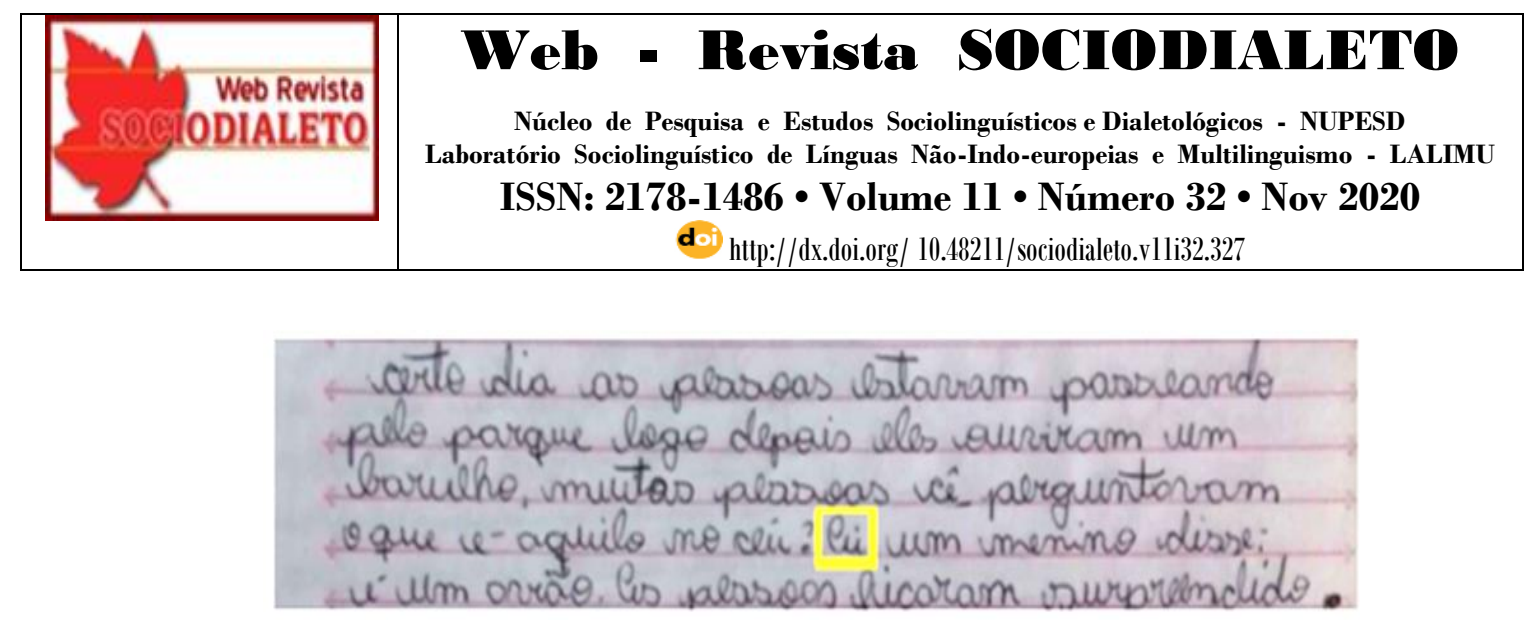

Figura 1: trecho retirado do texto escrito por F2.

Transcrição da figura 1:

Certo dia as pessoas estavam passeando pelo parque logo depois eles ouviram um barulho, muitas pessoas cê perguntaram o que é aquilo no céu? Ai um menino disse: é um avião. As pessoas ficaram surpreendido. (F2).

Exemplo 2:

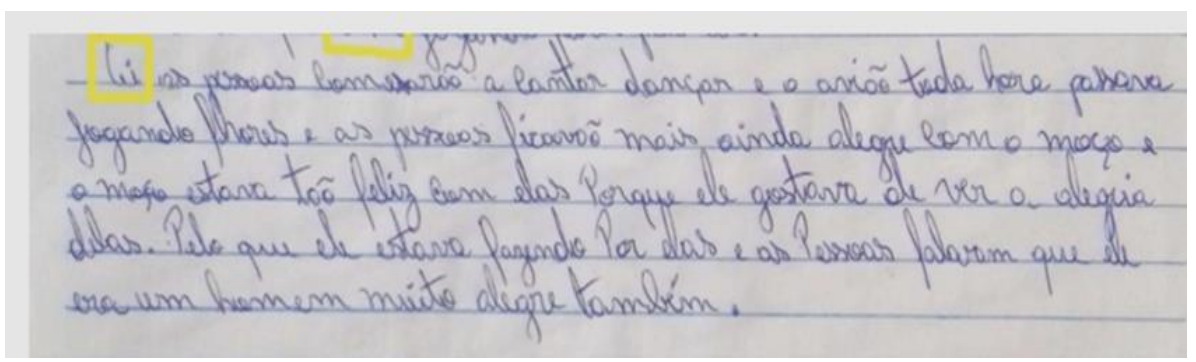

Figura 2: trecho retirado do texto escrito por M3.

Transcrição da figura2:

Ai as pessoas comesarão a cantar dançar e o avião toda hora passava jogando flores e as pessoas ficarão mais ainda alegre com o moço e o moço estava tão feliz com elas Porque ele gostava de ver a alegria delas. Pelo que ele estava fazendo Por elas e as Pessoas falavam que ele era um homem muito alegre também. (M3).

Exemplo 3: 

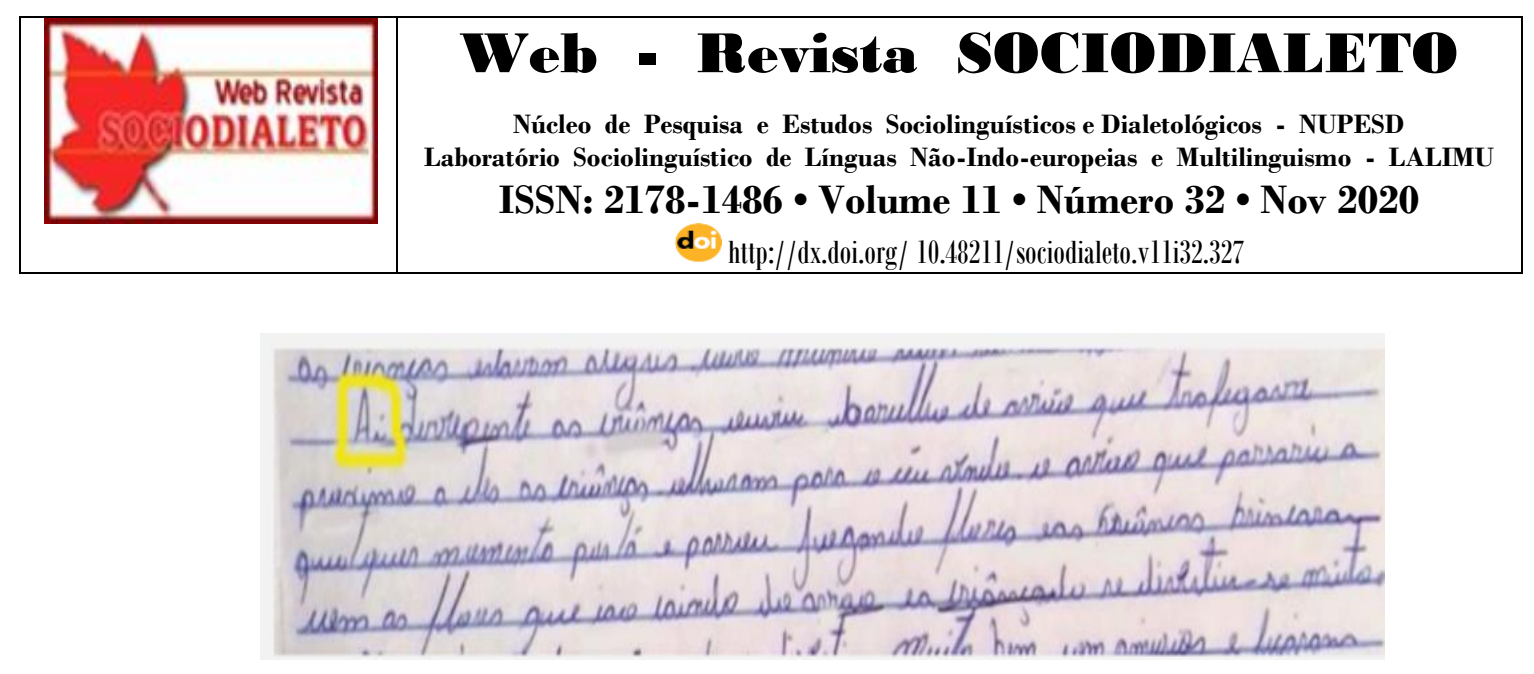

Figura 3: trecho retirado do texto escrito por M11.

Transcrição da figura 3:

Ai derrepente as crianças ouviu barulho de avião que trafegava próximo a eles as crianças olhavam para o céu vendo o avião que passaria a qualquer momento por lá e passou jogando flores as crianças brincavam com as flores que iao caindo do avião e as crianças se divertiu-se muito. (M11)

Verifica-se assim que, o marcador conversacional $a i$, tem frequência, e pode ser verificado nos textos dos alunos, podemos notar a repetição do fenômeno e o não enriquecimento do texto, que o torna mais coloquial.

2) $\mathrm{O}$ - mediai, muda-se muitas vezes em u

O segundo traço de oralidade encontrado foi observado três vezes nos textos analisados. Esse traço definido como o-mediai, muda-se muitas vezes em $u$. O abaixamento de vogal pode ser um fenômeno bem característico de cada região e ocorre nas mais variadas posições silábicas e em distintos processos de transformação.

Sobre esse fenômeno linguístico Amaral (1920) descreve:

- Mediai, muda-se muitas vezes em u: tabuleta, cusinha, dumingo, sobretudo nos infinitivos dos verbos em ir, que o têm na sílaba imediatamente anterior à tônica : ingulí(r), bulí(r), tussí(r), surtí(r). A possuir corresponde a forma dialectal 


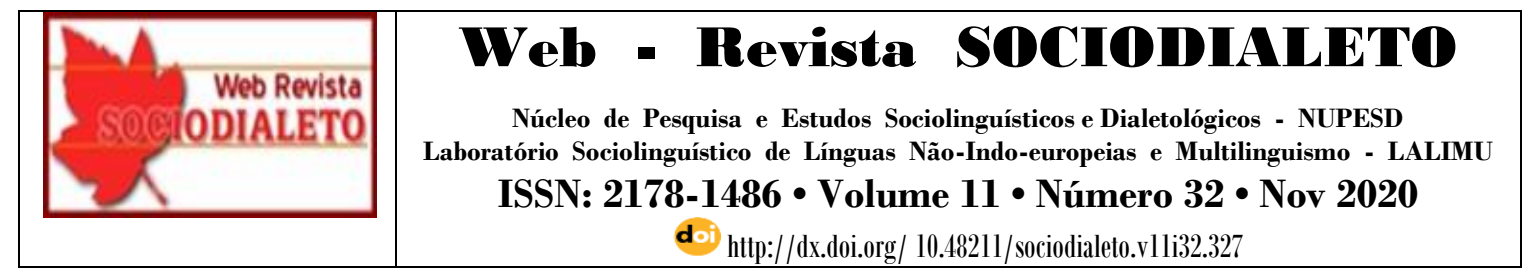

pissuí(r), que também existe em galego. (8) Nos infinitivos dos verbos em ar e er, conserva-se: cobrá(r), cortá(r), broqueá(r), intortá(r), sofrê(r), podê(r). Conserva-se também nos derivados e nas formas flexionadas, quando tônico nas palavras originárias: locura, boquêra, porcada, mortinho, rodêro. Conserva-se geralmente, aberto, nos deminutivos de nomes que o têm assim: pòrtinha, patinho, còbrinho (ao contrário do que se dá em outros pontos do país, notadamente em Minas, onde estes deminutivos têm o fechado) (AMARAL, 1920, p. 24).

Podemos mostrar essas ocorrências o-mediai, que muda-se muitas vezes em u nos exemplos que seguem:

Exemplo 4:

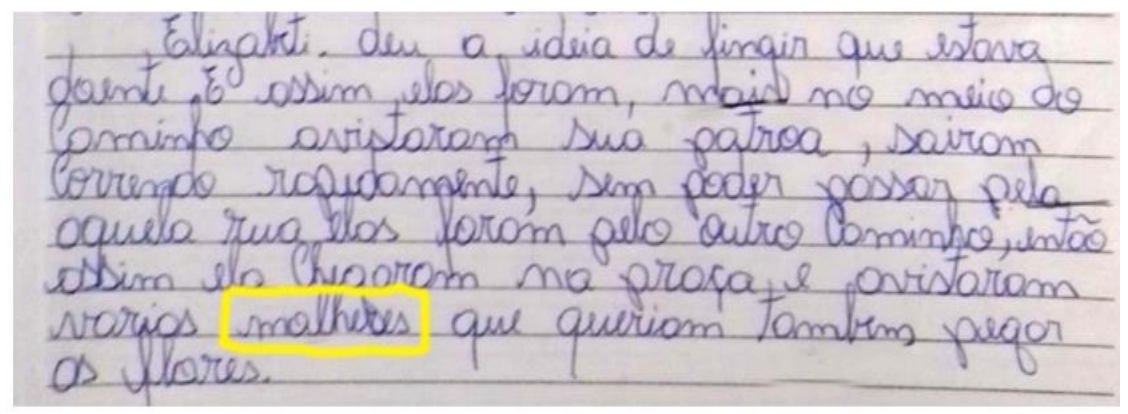

Figura 4: Trecho retirado do texto escrito por F4.

Transcrição da figura4:

Elizabeti deu a ideia de fingir que estava doente. E assim elas foram, mais no meio do caminho avistaram sua patroa, saíram correndo rapidamente, sem poder passar pela aquela rua elas foram pelo outro caminho, então assim ela chegaram na praça e avistaram várias molheres que queriam também pegar as flores. (F4).

Exemplo 5: 

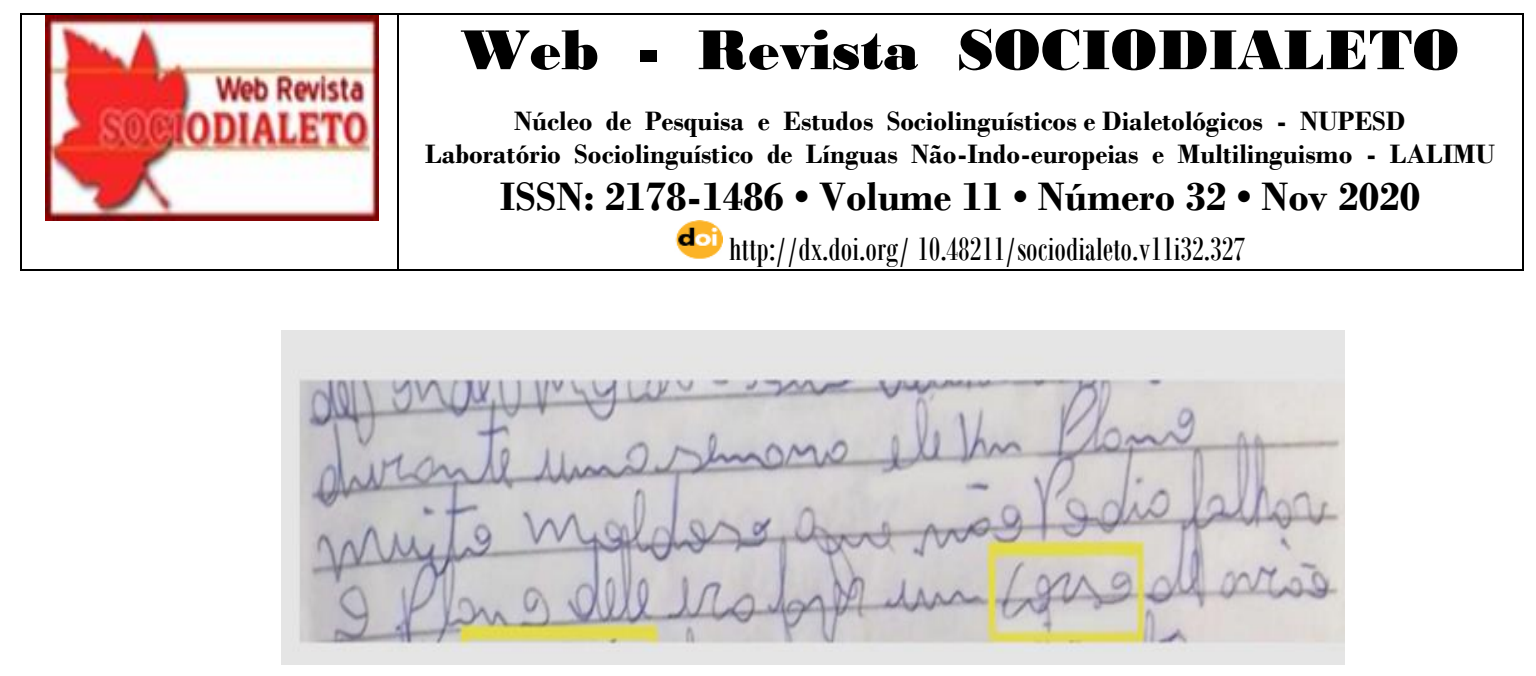

Figura 5: trecho retirado do texto escrito por M5.

Transcrição da ilustração 05:

[...] durante uma semana ele um plano muito maldoso que não podia falhar o plano dele era fazer um corso de avião [...]. (M5).

Exemplo 6:

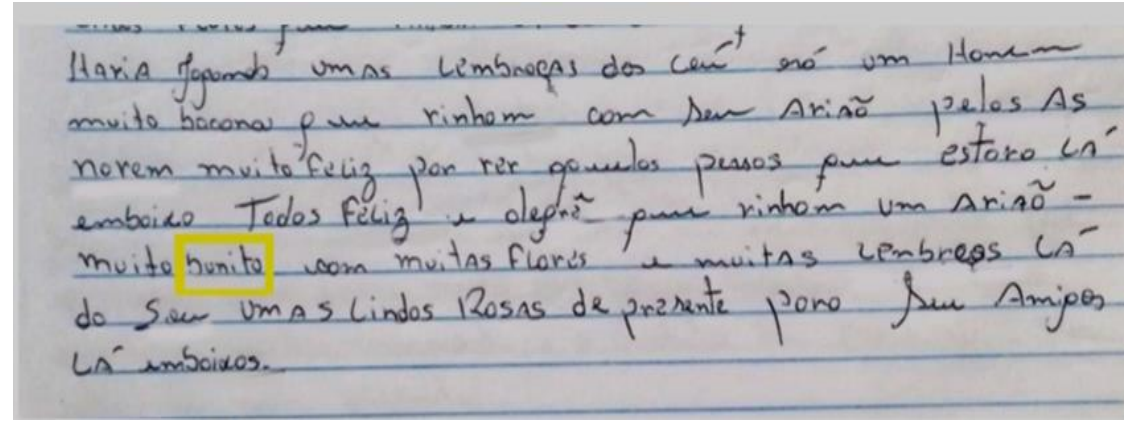

Figura 6: trecho retirado do texto escrito por M7.

Transcrição da figura 06:

[...] Havia jogando umas lembranças dos céu erá um Homem muito bacana que vinham com seu Avião pelas As novem muito feliz por ver aquelas pessoas que estava Lá embaixo Todas Feliz e alegrê que vinham um Avião muito bunito com muitas Flores e muitas lembrças Lá do Seu umas lindas Rosas de presente para seu amigos Lá embaixo (M7). 


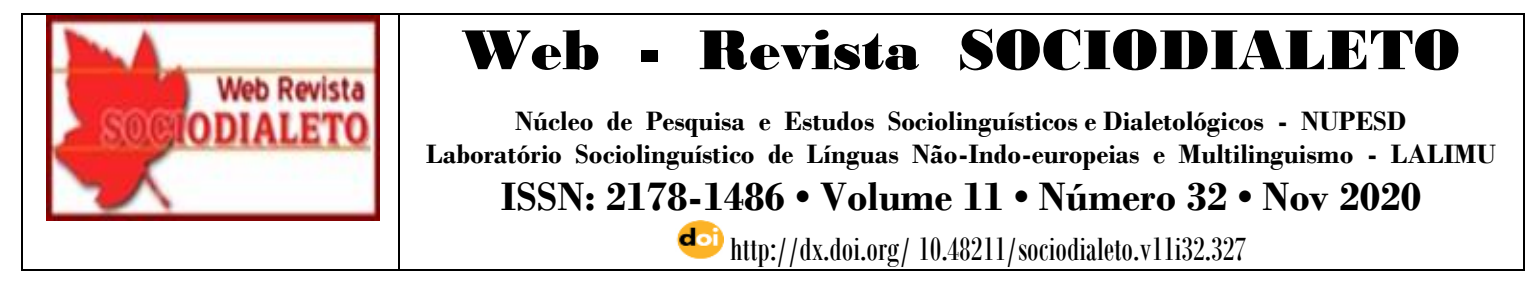

Com os exemplos 4, 5 e 6 percebemos que o fenômeno $o$ - mediai, que muda-se muitas vezes em $u$ aparece com frequência nos textos escritos por nossos alunos da escola observada.

3) A Vocalização do fonema /1/

O terceiro fenômeno encontrado, três vezes, nos textos escritos por nossos alunos foi observado em muitos outros trabalhos realizados sobre o assunto, todos verificaram que, em grande parte do território nacional, predomina a variante vocalizada dessa consoante, ou seja, o /l/ em final de sílaba transforma-se em uma semivogal [w], formando, muitas vezes, um ditongo com a vogal do núcleo da sílaba.

Sendo assim, palavras como mal e mau (ou vile viu) confundem-se numa mesma pronúncia: mau e viu. Podemos, portanto, afirmar que ocorre um processo de neutralização entre esses dois fonemas quando esses ocorrem em final de sílaba.

Sobre esse fenômeno linguístico Câmara Jr, observa:

[...] o contraste entre $/ \mathrm{l} / \mathrm{e} / \mathrm{w} /$ depois de vogal não deve ir ao ponto de se articular o /1/ depois de vogal exatamente como o /l/ antes de vogal... Salvo no extremo sul do país, esta pronúncia indiferenciada soa anômala, e dá a impressão de haver um ligeiro /i/ depois do /1/ de maneira que uma palavra como cal quase se confunde com cale ou mel com mele (CÂMARA JR., 1977, p. 31).

Exemplo 7:

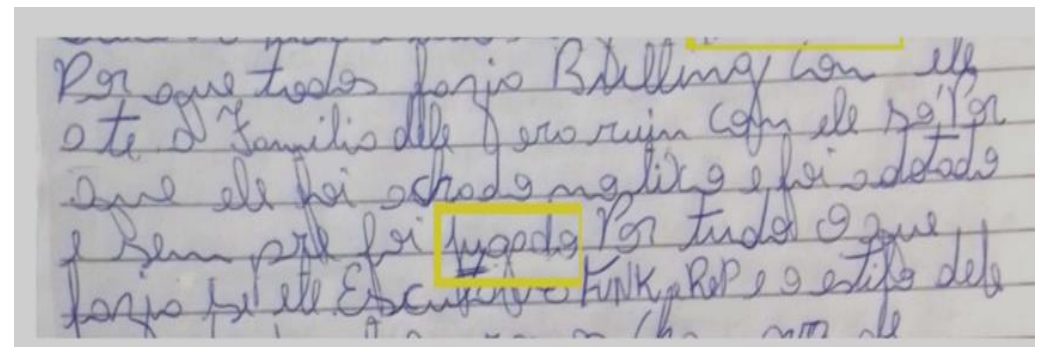

Figura 7: trecho retirado do texto escrito por M5. 


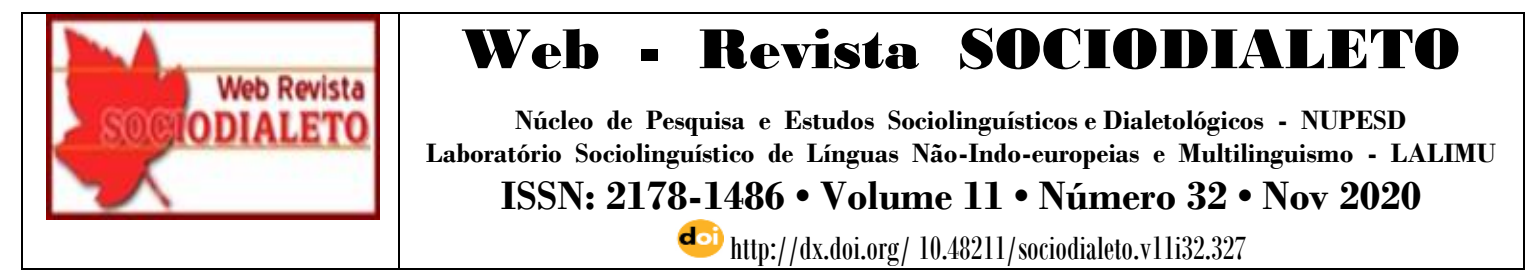

Transcrição da figura 07:

[...] Porque todos fazia bulling com ele ate a família dele era ruim com ele só Por que ele foi achado no lixo e foi adotado e sempre foi jugado Por tudo o que fazia se ele Escutava Funk, Rep e o estilo dele [...]. (M5).

Exemplo 8:

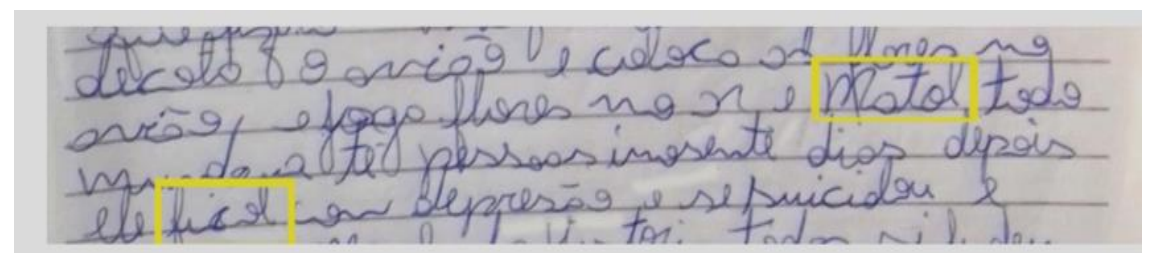

Figura 8: trecho retirado do texto escrito por M5.

Transcrição da figura 8:

[...] decola o avião e coloca as flores no avião e joga flores no ar e Matol todo mundo até pessoas inosente dias depois ele ficol com depressão e se suicidou e[...]. (M5).

Exemplo 9:

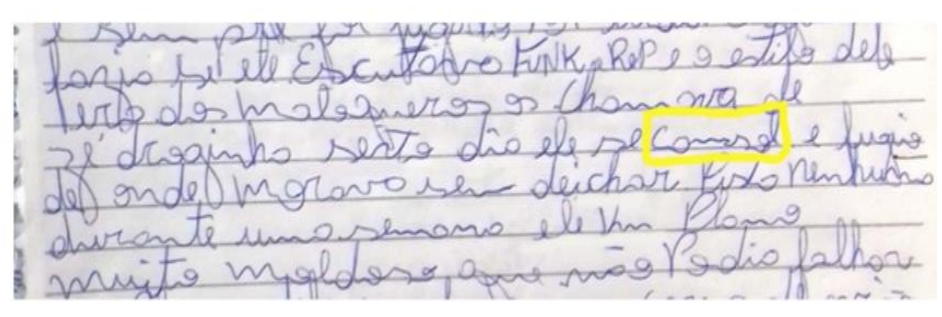

Figura 9: trecho retirado do texto escrito por M5.

Transcrição da figura 9:

[...] fazia se ele escutava Funk e Rep e o estilo dele era dos maloqueros os chamava de Zé droginha serto dia ele cansol e fugio de onde morava sem deichar Pista nenhuma durante uma semana ele Um plano muito maldoso, que não podia falhar [...]. (M5). 


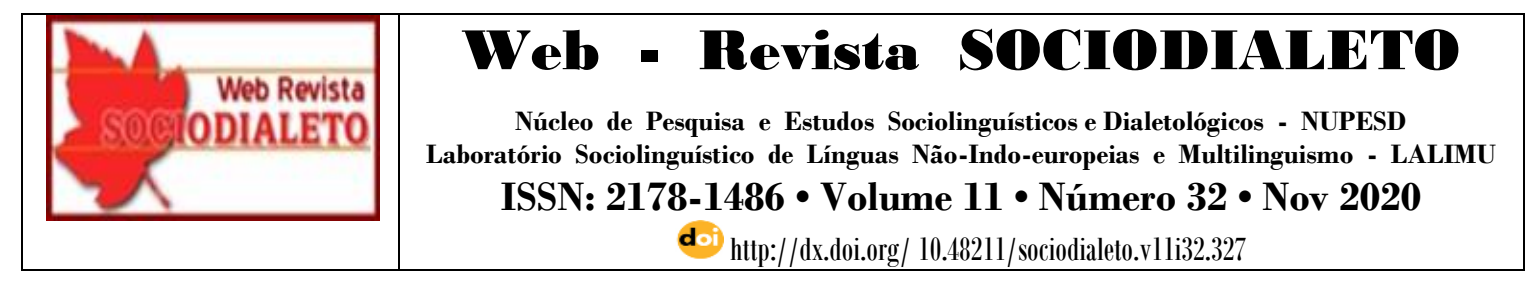

Com os exemplos expostos percebemos a frequência da utilização do fenômeno vocalização do fonema $/ /$ assim como os demais descritos.

\section{Considerações Finais}

A presente pesquisa foi desenvolvida na área da Sociolinguística, com o objetivo de apresentar os fenômenos comuns da fala na produção escrita de alunos do $1^{\circ}$ ano Ensino Médio. A partir das análises buscamos compreender e estabelecer uma ligação à prática pedagógica para torná-la mais eficiente.

Os resultados obtidos sanaram grande parte de nossas dúvidas, que nos levou a realizar este trabalho, percebemos que realmente existem traços de oralidade nos textos dos alunos, alguns ocorrem nos textos pelo desconhecimento da expressão "certa", e outros pertencem ao grupo em que os alunos estão inseridos na sociedade.

A partir de nossa análise, percebemos que ao estar inserido no contexto escolar, precisamos buscar meios que nos capacite para trabalhar essas variações existentes. Desse modo, cabe a nós professores, incentivar os alunos a leituras diárias para que melhorem seu repertório linguístico, pois é a partir da ampliação de leituras que o aluno se torna mais crítico e observador em sua escrita. Já o professor deve trabalhar a escrita e reescrita de textos, sem ficar apontando apenas o "erro" ou o "acerto".

Sobre esse aspecto Bortoni-Ricardo (2005), argumenta sobre o que a escola e os professores devem fazer em relação aos fenômenos linguísticos:

A escola não pode ignorar as diferenças sociolinguísticas. Os professores e, por meio deles, os alunos têm que estar bem conscientes de que existem duas ou mais maneiras de dizer a mesma coisa. E mais, que essas formas alternativas servem a propósitos comunicativos distintos e são recebidas de maneira diferenciada pela sociedade. Algumas conferem prestígio ao falante, aumentando-lhe a credibilidade e o poder de persuasão; outras contribuem para formar-lhe uma imagem 


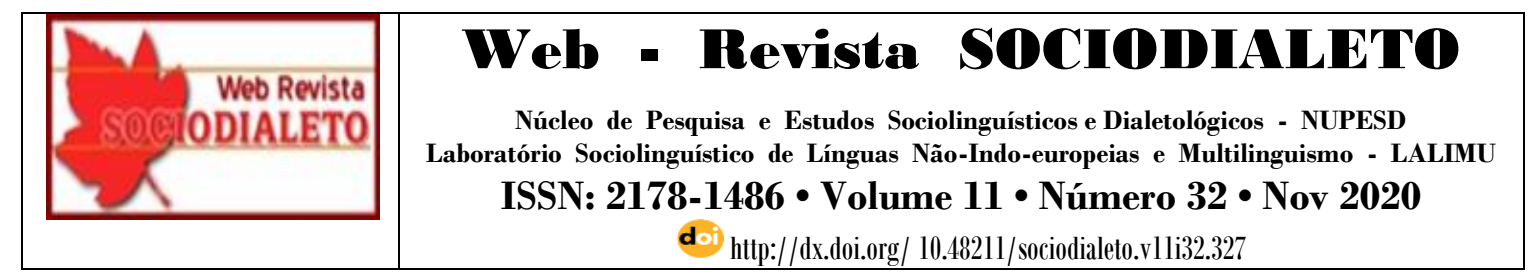

negativa, diminuindo-lhe as oportunidades. Há que se ter em conta ainda que essas reações dependem das circunstâncias que cercam a interação. Os alunos que chegam à escola falando "nós cheguemu", "abrido" e "ele drome", por exemplo, têm que ser respeitados e ver valorizadas as suas peculiaridades linguístico-culturais, mas têm o direito inalienável de aprender as variantes do prestígio dessas expressões. Não se lhes pode negar esse conhecimento, sob pena de se fecharem para eles as portas, já estreitas, da ascensão social (BORTONI-RICARDO, 2005, p. 15).

Percebe-se que esses fenômenos devem ser apresentados aos alunos para que tomem conhecimento que existe mais de uma forma de falar a mesma coisa, a forma de falar vai depender de toda circunstância que cerca o momento da interação. Além disso, os professores e os alunos devem buscar conhecimento sobre as variações linguísticas e conhecer sobre a língua brasileira, essa que sempre estará em constante movimento, a língua que utilizamos para nos comunicarmos de forma oral e escrita.

Concluímos nossa pesquisa enfatizando que é preciso trabalhar as questões da variação linguística, as regras da língua falada e escrita, a compreensão da prática pedagógica em relação aos fenômenos linguísticos nas disciplinas de língua portuguesa, principalmente nas aulas de produção textual, no que diz respeito à "correção" dos professores nos textos dos alunos.

\section{Referências}

ALKMIM, Tânia Maria. Sociolinguística. Parte I. IN: MUSSALIM, Fernanda; BENTES, Ana Cristina. Introdução à linguística: domínios e fronteiras, v.1, 6ed. São Paulo: Cortez, 2006. p.21-47.

AMARAL, A. O dialeto caipira. 3. ed. São Paulo: Hucitec-SCET-CEC, 1976. [1920].

BAGNO, M. Preconceito linguístico: o que é, como se faz. São Paulo: Loyola, 2007.

BORTONI - RICARDO. Stella. Maris. A linguística na escola. In: Cuiabá, 2004 a. Disponível em: <http://www.sbpcnet.org.br/livro/56ra/banco_conf_simp/ textos/StellaRicardo.htm>. Acesso em 20 de Jan. 2019.

BORTONI - RICARDO. Stella. Maris. Educação em língua materna: a sociolinguística na sala de aula. São Paulo: Parábola, 2004 b. 


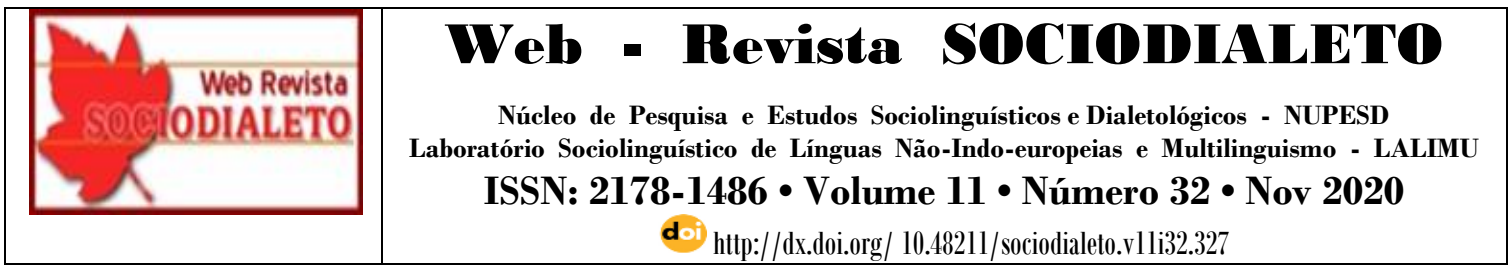

BORTONI - RICARDO. Stella. Maris. Nós cheguemu na escola e agora?: Sociolinguística e educação. São Paulo: Parábola, 2005.

BORTONI - RICARDO. Stella. Maris. O estatuto do erro na língua oral e na língua escrita. In: GORSKI, M. E; COELHO, I. L. (Orgs.). Sociolinguística e ensino: contribuições para a formação do professor de língua. Florianópolis: Ed. da UFSC, 2006.

BORTONI - RICARDO. Stella. Maris. O professor pesquisador: introdução à pesquisa qualitativa. São Paulo: Parábola, 2008.

BRAGA, Maria Luiza \& MOLLICA, Maria Cecilia. Introdução à Sociolinguística: o tratamento da variação. 2ed. São Paulo: Contexto 2004.

BRASIL ESCOLA. Monografias, Variação linguística, uma realidade de nossa língua. Disponível em<https://monografias.brasilescola.uol.com.br/educacao/variacaolinguistica-uma-realidade-nossa-lingua.htm>Acesso em 05 de Maio 2020.

CAGLIARI, Luiz Carlos. Alfabetização e linguística. São Paulo: Scipione, 2007.

CALVET, Louis-Jean. Sociolinguística: uma introdução crítica. São Paulo: Parábola, 2002.

CÂMARA JR., J. M. . Estrutura da língua portuguesa. 41 ed. Petrópolis: Vozes, 2008.

COELHO, IzeteLehmkuhl, [et al.]. Sociolinguística- Florianópolis LLV/CCE/UFSC, 2012.

COELHO, L. C. Oralidade Presente Na Escrita De Alunos Do II Ano Do Ensino Fundamental.2012. 6f. Universidade Estadual do Sudoeste, Bahia, 2012.

DIA A DIA EDUCAÇÃO. Conselho Escolar. Disponível em<http://www.gestaoescolar.diaadia.pr.gov.br/modules/conteudo/conteudo.php?conte udo=279> Acesso em 23 de Jun. de 2019.

FARACO, Calos Alberto. Norma culta brasileira: desatando alguns nós. São Paulo: Parábola, 2008.

FARACO, Carlos Emílio; MOURA, Franscisco Marto de, MARUXO JR, José Hamilton. Língua Portuguesa: linguagem e interação.2. ed. São Paulo: Ática,2013.

KOCH. I. V. e TRAVAGLIA. L. C. A coerência textual. São Paulo: Contexto, 2010, p. 10.

LABOV, William. Sociolinguistic Patterns. Pennsylvania: University of Pennsylvania Press, 1972.

MACEDO-KARIM, Jocineide Macedo. (2012). A comunidade São Lourenço em Cáceres-MT: aspectos linguísticos e culturais. Tese de Doutorado. Campinas-SP: UNICAMP, Universidade Estadual de Campinas.

MARCUSCHI, L. A. Da fala para a escrita: atividades de retextualização. 10. ed. São Paulo: Cortez, 2010. 


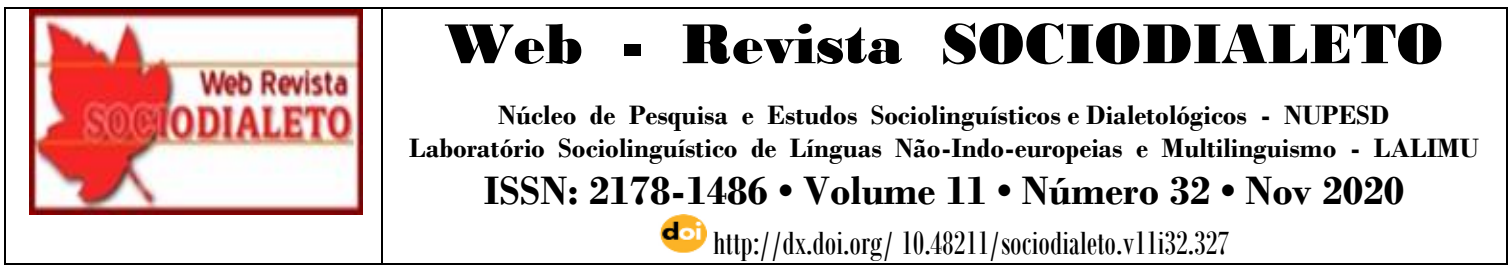

MARCUSCHI, L. A. Marcadores conversacionais no português brasileiro: formas, posições e funções. In: CASTILHO, A.T. de (org) Português culto falado no Brasil. Campinas: Ed. Da Unicamp, 1989, p. 281-322.

PCN's. Parâmetros curriculares nacionais ensino médio. Disponível em<http://portal.mec.gov.br/seb/arquivos/pdf/linguagens02.pdf >Acesso em 20 de Jan. 2019.

SILVA, B. N., A Marca Da Oralidade Na Produção Escrita De Alunos Do $6^{\circ}$ Ano Da Escola Criança Cidadã Na Cidade De Cáceres - MT.2017/1.12f. Monografia para conclusão de curso Licenciatura em letras, Cáceres, 2017/.

TARALlO, F. A pesquisa Sociolinguística. São Paulo, Ática. 1990.

Recebido Para Publicação em 19 de setembro de 2020.

Aprovado Para Publicação em 21 de novembro de 2020. 